\title{
Model Design for Evaluation of Educational Buildings in terms of Emergency Situations and Increasing their Reliability Levels
}

\author{
Eğitim Binalarının Acil Durumlar Açısından Değerlendirmesi ve \\ Güvenilirlik Düzeylerinin Arttırılmasına Yönelik Model Tasarımı
}

\begin{abstract}
Educational institutions are also affected by emergencies and education and training can be paused. Making educational institutions safe in emergencies is important both for individuals and for continuing education. The aim of this study is to design a model that will eliminate the shortcomings of educational institutions and make them safer.

In this thesis, researches, regulations, and laws on the same national and international issues are examined by using the method of examination to make educational buildings more secure. As a result of the review, 8 main headings were created in the guideline designed as follows: Structural and non-structural, security, environmental, fire, evacuation, health, electricity, and the general form are formed. A total of 120 questions were evaluated. As an example, guidance was applied to the selected school. Only 100 criteria were used in the evaluation. As a result of the study, 52 criteria were evaluated as positive and 48 criteria as negative. This evaluation guide, it is aimed to make the institutions more secure. In the next phase, it is expected to guide the studies on the same subject.
\end{abstract}

\section{Öz}

Acil durumlardan eğitim kurumları da etkilenmekte ve eğitim-öğretime ara verilmek zorunda kalınabilmektedir. Eğitim kurumlarının acil durumlarda güvenli hale getirilmesi hem kişiler açısından hem de eğitimin devam açısından önemlidir. Bu çalışmanın amacı eğitim kurumlarının eksikliklerinin giderecek ve daha güvenli hale getirecek bir model tasarlamaktır.

Bu tezde de eğitim binalarının daha güvenli hale getirilmesi için irdeleme yöntemi kullanilarak ulusal ve uluslararası aynı konuda yapilan araştırmalar, yönetmelikler, kanunlar incelenmiştir. Inceleme sonucunda tasarlanan kılavuz içerisinde 8 ana başlık oluşturulmuş oluşturulan genel başlıklar, yapısal ve yapısal olmayan, güvenlik, çevresel, yangın, tahliye, sağlık, elektrik ve genel başlıklarıdır. Toplamda 120 soruluk değerlendirme kriterleri belirlenmiştir. Örnek olarak belirlenmiş olan okul üzerinde kılavuz uygulanmıştır. Yapılan çalışma sonucunda değerlendirme yapılabilen 100 kriterden 52 kriter olumlu ve 48 kriterde olumsuz olarak değerlendirilmiştir. Oluşturulan bu değerlendirme kılavuzu ile kurumlarn daha güvenli hale getirebilmek hedeflenmiştir. Bu çalışma bundan sonra aynı konu üzerindeki çalışmalara yol gösterici olacă̆ı beklenmektedir.

\section{Introduction}

Our country has quite a history of disasters. Turkey mainly earthquakes, landslides, forest fires, are experienced multiple disasters such as floods and avalanches. While more than 100,000 people lost their lives due to 285 earthquakes and earthquakes of more than 4 magnitudes reported from 1900 to 2010, nearly 650,000 residences were heavily damaged (Koçkan, 2015: 1-8). In our schools, we may encounter many situations that require emergency intervention. To make our schools safer, it is necessary to prepare plans for disaster and emergencies and to make risk assessments of each school on its scale and with its local characteristics.

\begin{abstract}
Saim Demirel
Öğretim Görevlisi, Yozgat Bozok

Üniversitesi, saim.demirel@bozok.edu.tr,

Orcid: 0000-0003-2428-6384

Sevil Cengiz

Üniversitesi, sevil_cengiz@yahoo.com,

Orcid: 0000-0002-3562-1793
\end{abstract}

Article Type / Makale Türü

Research Article / Araştırma Makalesi

Anahtar Kelimeler

Acil Durum, Acil Durum Yönetimi, Eğitim

Binalar.

Keywords

Emergency, Emergency Management,

Bilgilendirme

Çalışma Yüksek Lisans Tezinden Üretilmiştir.

Submitted: $\quad 16 / 12 / 2020$

Accepted: $13 / 01 / 2021$ 
If we look at our schools affected by our past disasters, in the Bingöl earthquake, which was 6.4 in size and determined as 03.27, on May 1, 2003, the dormitory building and the school building of the Regional Boarding School collapsed completely, and as a result of this collapse, 1 of our teachers and 84 students died (TMMOB, 2003: 127). In the Simav earthquake that occurred in 2011, 7 schools and 234 schools were severely damaged in the earthquakes in Van on 23 October and 9 November in 2011 and had to suspend education for a long time (IMO, 2011).

According to official figures, 17,479 people died and 43,953 people were injured in the 6.7 magnitude Izmit Bay earthquake that took place on August 17, 1999, at 03:02. In total, 43 schools were destroyed and 377 schools were identified as damaged. In general, 77 thousand heavy, 77 thousand medium, and 89 thousand slightly damaged houses or workplaces(Özmen, 2000: 132) While the place and importance of disaster education is so clear, it is necessary to take precautions to improve this situation and to fill the gaps in our country. It is obvious that making plans for emergencies, controlling the plans, and implementing the plans will carry the security in the school to our home. In 2016, we see that a little boy studying in a kindergarten in Gaziantep saved his family from stove poisoning after the hands-on training is given by firefighters (Türkiye Gazetesi, 2019).

\section{Materiel and Method}

\subsection{Type of Study}

The study a descriptive.

\subsection{Purpose of the study}

The purpose of this study is to determine the deficiencies by evaluating the responsiveness of our educational institutions to emergencies and to increase the reliability of the institutions by ensuring that the identified deficiencies are eliminated. In this way, educational buildings will increase their responsiveness to emergencies that may occur and will become safer and more livable.

\subsection{Study Objectives}

In my work, the main goal of the study is to reveal the plans and analyzes that each institution has created on its terms and to offer suggestions in the transition from ready-made molding to a new order, thanks to national and international researches and regulations.

\subsection{Importance of the Study}

Educational institutions are among the institutions that should have continuity after disasters. After many disasters, individuals had to temporarily interrupt their education life or continue their education under unsuitable conditions. The safety of people who will be exposed to disasters during training is also ignored by standard plans. Therefore, it is necessary to ensure that educational institutions can continue to serve from disasters.

If we think in terms of families, every family wants to send their children to a safe school. When today's conditions are evaluated, many conditions that affect school safety, such as the use of harmful substances, emerge in our country. Therefore, it is obvious that the quality of education in our country will increase when both safe educational institutions and educational institutions that respond rapidly to emergencies are designed or their problems are solved with the studies carried out in their current situation. The researches, examinations, and the criteria made in this thesis will be useful when making plans that will be a guide for the safety of educational institutions.

\subsection{Scope of the Study}

The national and international emergencies in educational buildings and regulations that are compatible with the scope of reliability are examined, the results of the articles and theses written on the same subject are evaluated and the results of the world and the risk dimensions of these consequences will be evaluated as a result of the analysis and analysis of emergencies to contribute to the school disaster plans.

\subsection{Method}

By using the examination method, special provisions, regulations, plans, and studies regarding both national, and international emergencies have been researched, and the areas to be evaluated, evaluation criteria, reporting draft has been created to be used in the modeling we will create as a 
result of the research. The designed modeling is given as Annex-1 in the thesis. With the created modeling, a study was carried out in Fevzi Paşa Primary and Secondary School. The results of the investigation were reported by evaluating the $\mathrm{L}$ matrix risk analysis method.

\section{Result}

Evaluation of the guide prepared as a result of the study was implemented in Gümüşhane Fevzi Paşa Primary and Secondary Education Institution. The establishment year of the institution is 2008. It has 5 floors including the basement and ground floor. The heating system is central heating (Natural Gas).

The total number of personnel is 44 . It serves as 10 men and 34 women. There are 5 trainee students. The number of students is 250 in total, 136 males and 124 females for primary education, and the number of secondary school students is 204, including 106 males and 98 females.

One of these students is physically disabled. There are 23 students with mild mental disabilities. The type of building is reinforced concrete. There are 2 fire stairs in the school. 1 security personnel controls the entrances and exits.

The table of criteria included in the evaluation is as follows;

Table 1. Guideline Evaluation Conducted in a Sample School

\begin{tabular}{lcccc}
\hline $\begin{array}{l}\text { Evaluation } \\
\text { Area }\end{array}$ & $\begin{array}{l}\text { Total } \\
\text { Criteria } \\
\text { Number }\end{array}$ & $\begin{array}{c}\text { Number of } \\
\text { inaccessible } \\
\text { Criteria }\end{array}$ & $\begin{array}{c}\text { Positive } \\
\text { Criterion } \\
\text { Number }\end{array}$ & $\begin{array}{l}\text { Negative } \\
\text { Criteria } \\
\text { Number }\end{array}$ \\
$\begin{array}{l}\text { Evacuation and Escape } \\
\text { Route }\end{array}$ & 29 & 2 & 13 & 14 \\
Environmental & 15 & 5 & 2 & 8 \\
Fire & 23 & 5 & 14 & 4 \\
Health & 12 & 3 & 5 & 4 \\
Structural and Non- & 16 & 3 & 6 & 7 \\
structural & 10 & 1 & 5 & 4 \\
Electricity & 9 & 1 & 4 & 4 \\
Security & 6 & 0 & 3 & 3 \\
General & 120 & 20 & 52 & 48 \\
TOTAL & & & 5 & 4 \\
\hline
\end{tabular}

As can be seen from the table, 20 criteria in total could not be reached or could not be evaluated because there was no suitable field. While the number of criteria evaluated was 100,52 positive 48 negative criteria were obtained. Risk scoring was created according to the criteria determined negatively and the L-matrix method.

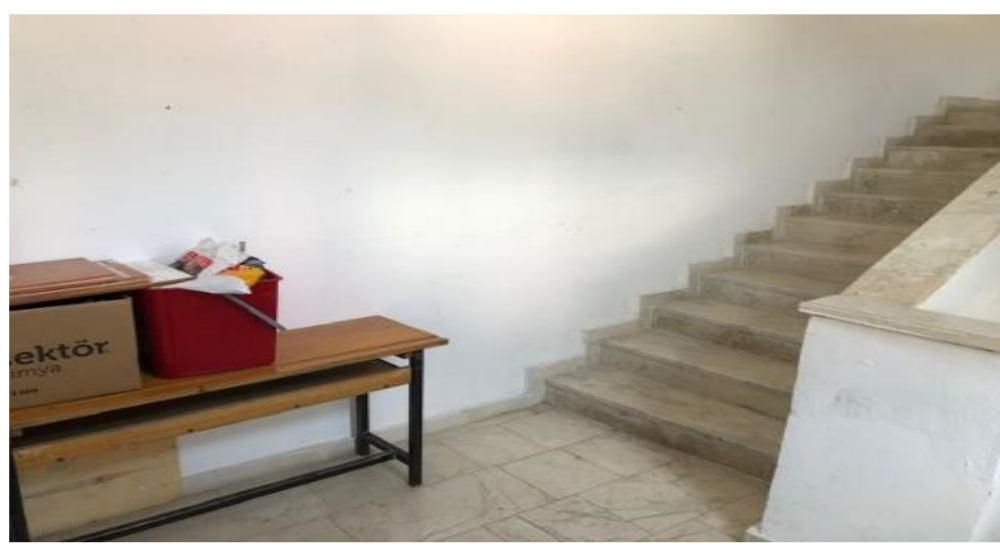

Figure 1. The obstacle in the Fire Escape and Not Using Anti-Slip Tapes

Source: Created by Researcher 
While the width of the escape routes, step heights, and step widths was appropriate, it was determined that the last exit doors on the escape route were locked. While the opening directions of the classroom doors were appropriate, it was determined that the doors of the boiler room, archive, toilet, and some other office rooms opened inside. No work has been observed on the floor plans and evacuation plans in the school. Emergency exit doors are designed in accordance with the standards. It was determined that there was a table tennis table in front of the ground floor emergency exit doors and the doors were locked. The first and last steps on the escape route are not in different colors. There is a smoke detector throughout the school, but it has been determined that no sprinkler system is used.

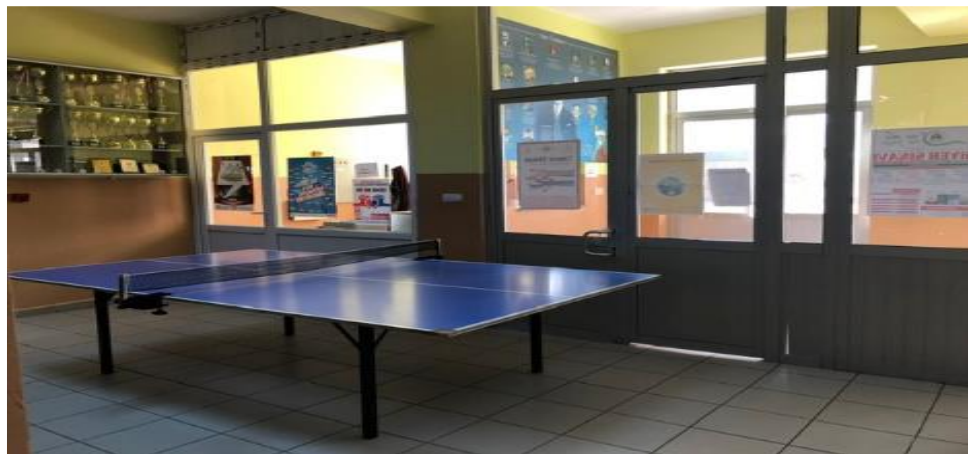

Figure 2. Painting Obstacles on Emergency Exit Roads

Source: Created by Researcher

It was determined that tables, smart boards, and projectors were fixed throughout the institution. However, it was observed that bookshelves, archive cabinets, and other cabinets were not fixed. It is among the observations that the televisions and computers in the institution are still not fixed. A general study of emergency signs has been done, but not sufficient. It was observed that there were no markings on the fire cabinets and the electrical panels on the buttons.

There are not enough tables for emergency phones. There are direction signs for emergencies, but some are damaged and do not have sufficient light. The emergency route is not sufficiently illuminated. There is no ventilation system in the emergency exit stairs. It was determined that antislip tape on the stairs throughout the school was used only on the education and training floors, and no anti-slip tape was used on the stairs of the 4th and basement floors. While there was no suitable extinguishing equipment in the laboratories, it was observed that the fire cabinets were in compliance with the standards and the controls and pressures of the fire tubes were at the appropriate level.

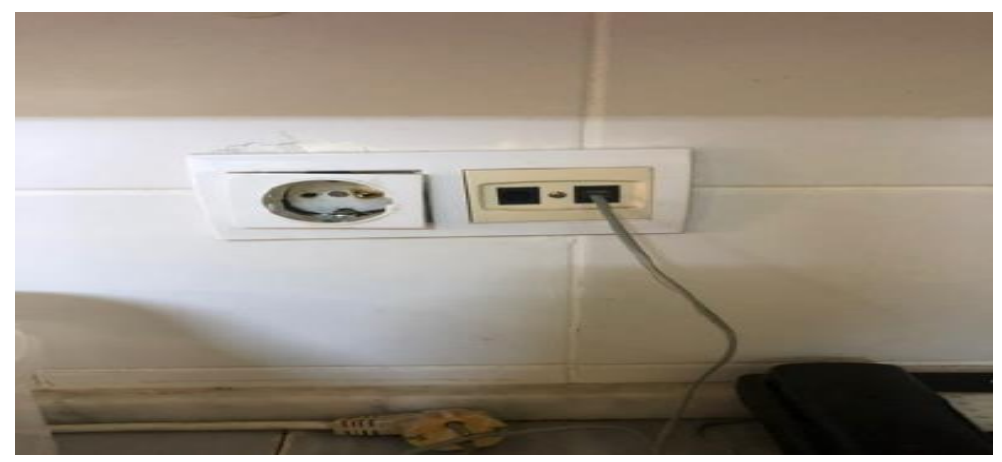

Figure 3. Inappropriate Socket

Source: Created by Researcher

It has been determined that there is no hood system in the canteen located on the 2nd floor of the school and the extinguishing device in the canteen is kept on the ground. There is a hydrant system outside the building, but this hydrant system is not suitable for the conditions and water discharge. There is an extinguishing device suitable for fuel and a detector for leakage in the boiler room. The director of the institution informed the institution that fire training is regularly organized 
and that the students of the Emergency Aid and Disaster Management departments recently provided training for secondary school on disasters.

It has been informed that the boiler room is activated at a certain time when it is arranged automatically and deactivated at a certain time. While the sinks were clean in terms of health, health warnings were not posted. Litter boxes in classrooms and throughout the institution are uncovered. There is a health room and it has been found out that there is 2 personnel with first aid certificates throughout the institution. The cafeteria serves under suitable conditions.

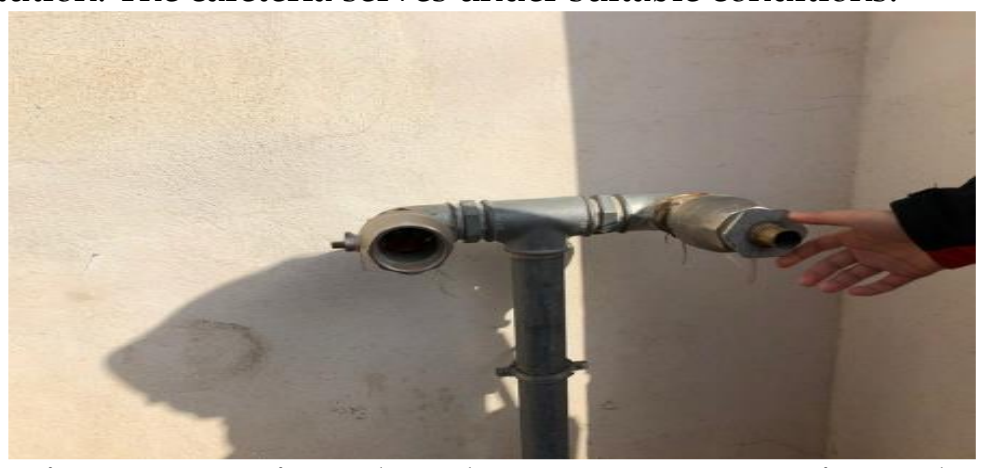

Figure 4. Keeping Obstacles on Emergency Exit Roads

Source: Created by Researcher

No protection on the radiator cores. It has been determined that the sockets are not covered. Access to electrical panels is restricted and fuses are in the shelter. There is no alternative power source. It is informed that there is a residual current relay connected to the mainline. An insulated mat carpet was not used in electrical panels. Classroom lighting is sufficient in terms of ergonomics. Main gate entrances are kept open at all times and it has been observed that visitors are not reported. Security cameras are designed to show every angle. Garden walls are bordered for foreign clay entrances. No searches are made on students for piercing and cutting tools or other dangerous elements.

There is no floor plan or evacuation plan hanging on the floors. Emergency teams have been identified and team lists have been posted on the fire cabinets. It was informed that fire drills were held. An emergency meeting area has been determined, but there is no sign. Crevices for rainwater could not be detected in the institution garden. There is no speed sign or information about the school district outside the institution. It was observed that vehicles were parked inside the institution, but there is no speed sign.

There is no afforestation within the borders of the institution, but trees outside the wall do not pose any danger. The septic tank and sewer pits in the garden are safe and cannot be opened, but the lids here appear to be pitted as they are below the level of the garden floor. The goalposts in the school are designed to prevent falling. It has been determined that there is no ramp on one side of the ramp for the disabled.

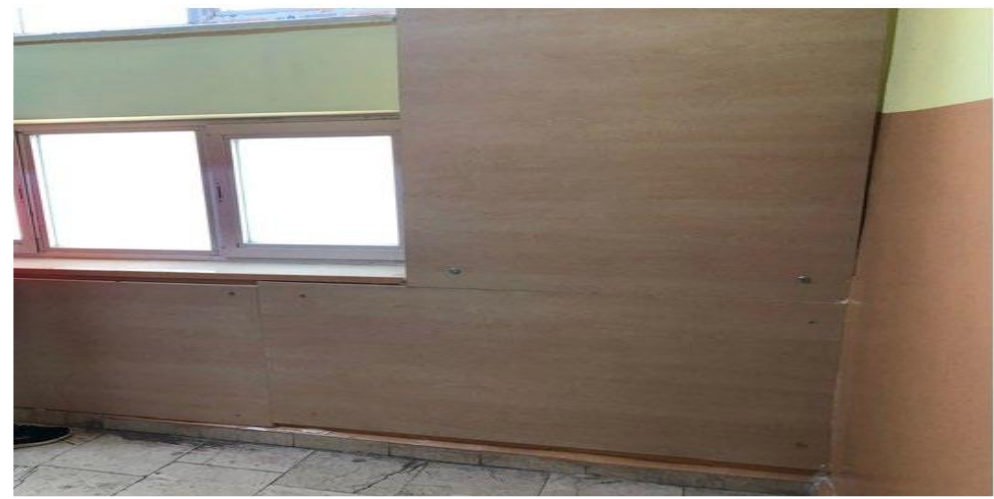

Figure 5. Precaution Taken for Structural Damage

Source: Created by Researcher 
By using the L-Matrix risk analysis system, the probability of occurrence of hazards, and the severity of damages, damages, and injuries that may arise as a result are multiplied by the weight ratios of the risks. According to the risk scores of the criteria that are considered negatively in the evaluation, I made with the L-Matrix method; It has been determined that there are 5 criteria with very high risk. 15 criteria were identified as high risk, 24 criteria as medium risk, and 4 criteria as low risk. If we consider it as the main title of the criterion; The 7th evaluation criterion for fire is very high, the 1st evaluation criterion is high, the 21st evaluation criterion is medium and the 12th evaluation criterion is low risk. For the structural and non-structural criteria, the 3rd evaluation criterion is high and the $2 \mathrm{nd}, 9$ th, 10 th, 11 th, 12 th and 14 th evaluation criteria are medium risks. In the environmental criteria, the 14th evaluation criterion is very high, the 9th and 13th evaluation criteria are high, and the 1st, 4 th, 8 th, and 10th evaluation criteria are a medium-level risk.

In the evaluation made for electricity, the 6th, 7th, and 9th evaluation criteria are high and the 8 th evaluation criterion is medium risk. The $3 \mathrm{rd}, 6 \mathrm{th}, 11 \mathrm{th}$, and 12 th evaluation criteria for health were identified as moderate risk. Among the evacuation and escape route criteria, the 18th and 24th evaluation criteria are very high, the 4 th, 5 th, 7 th, 8 th, 10th, 11th and 30th evaluation criteria are high and the 6th, 9th, 15th, 28th And 29. evaluation criteria identified medium risk. The 7th and 8th evaluation criteria for security are medium risks and finally, in the General section, the 6th evaluation criterion is very high, the 1 st evaluation criterion is high and the 2 nd evaluation criterion is medium risk.

\section{Conclusion and Evaluation}

The location of the emergency is very important in education buildings. Plans specified in the standards are arranged, but in many educational buildings, these arrangements remain only as plans. As can be seen in the examination, we have deficiencies not only nationally but also internationally. It is important to ensure continuity after disasters in terms of not interrupting education and training life.

In the research, both national and international studies, regulations, standards, obligations, and items that will accelerate the response to possible situations were determined, especially by reducing the effects of emergencies. Thanks to these items, institutions will be able to score their possible risks and learn the extent of the risk. All risks will be minimized sequentially by prioritizing the risk size. When we applied the guide we created in the sample school, the school was rated as positive at $52 \%$.

In the study prepared by Akpinar and Köksalan (2010), using descriptive scanning model to determine to what extent schools with important duties and responsibilities in preparing for the state of emergency and overcoming extraordinary situations that will be experienced, they perform their duties in elâzı ̆̆ Data were obtained by surveying 56 school principals who were randomly selected (Akpinar ve Köksalan, 2003: 151-158). As a result of the percentage and frequency analysis, $86 \%$ of the administrators answered the question of whether there is planning, which is very important in dealing with extraordinary situations, and $14 \%$ did not. $61 \%$ of the school administrators answered yes and 39\% answered no to the question about whether training or conferences are given in relation to extraordinary situations at school. To the question asked about the exercise, $71 \%$ of them stated that the exercises were done in the schools and $29 \%$ were not. To the question asked about the preparedness of the school for a possible disaster, $14 \%$ of the school principals stated that they were completely ready, $54 \%$ stated that they were ready at medium level and $32 \%$ were ready at a low level. In the question asked for the evaluation of the suitability of the school building for shelter and shelter during any disaster that may occur, $29 \%$ were completely suitable, 39\% were at a medium level and 32\% were at a low level.

To determine the effects of security measures taken in schools by Peruman-Chaney and Sutton (2013) on students' perceptions of school safety, 13,386 students studying in 130 different schools were used to use the "In-Home Adolescent Survey" and 130 administrators The information was collected with the scale named "Administrator Questionnaire" and Linear Model Analysis was performed (Peruman \& Lindsay, 2013: 570-588). As a result of the analysis, it was seen that the use of metal detectors and physical security measures had a negative effect on students' perceptions. 
Lennon and Moore, the purpose of their work on "The concept of natural fire safety and fullscale tests in Cardington"; In the experiment of a compartment with actual dimensions $(12 \mathrm{~m} \times 12 \mathrm{~m})$, to obtain information about the situation in the space after the flashover event (Lenon \& Moore, 2003: 623-643). This study is one of the 8 full-scale fire experiments in Cardington, England, in collaboration with the European Union research program.

Kişioğlu, Demirel, and Öztürk (2005), in the study, aimed to evaluate the interiors of 37 primary schools in Isparta in the context of school safety (Kişioğlu and Öztürk, 2005: 141-145). As a criterion, TS 9518 numbered "Primary schools, Physical security and General rules "and TS 12014" Environmental health, schools "standards. It was determined that only 3 out of 37 schools had first aid kits, and 2 aid vehicles were found in 2 of them. It has been determined that only 4 of the schools have emergency exit stairs. It was determined that 3 of the schools had one or more classrooms in the basement. These classes carry a great risk in terms of earthquake safety.

Marrion, Mike, and Kodur (2004) examined the fire behavior of materials in their study on "Overview of fire safety in buildings." Fire safety In the United States, standard test methods for fire in terms of building materials (ASTM-Standard Test Methods for Fire Test of Building Construction and Materials) and the process of transforming these standards from imperative to performancebased obligations. In the continuation of the same article, with the experiments made according to the American standards ASTM-E119 and ASTM E1529, a comparison with graphics was made on the temperature differences of the Hudson Terminal building, which is a real fire, according to the time during the fire (Marrion, Mike, and Kodur, 2004: 550-560).

A field study was carried out by Barnes (2013) to determine the needs of students with disabilities in school disasters. Studies conducted a literature review and as a result, it has been observed that a solution and approach for the lack of a school disaster planning or preparation for students with disabilities or special health needs has been found today (Barnes, 2013).

In a survey conducted by Fox, Rooney, and Rowland (2007) supported by the U.S. Department of Security, only $69 \%$ of emergency managers in each state and each metropolitan area reported that people with disabilities were included in emergency plans. $69 \%$ of them were pediatric It has been determined that there is no plan for the mass. In districts that have experienced disasters before, only $20 \%$ of them have guides for the disabled (Fox, Rooney and Rowland, 2007: 196-205).

Improving education institutions in terms of disaster and emergency management planning in Turkey or the system is at an early stage. When we look at the international studies, the importance given to planning and exercises is more. With the "Law on the Organization and Duties of the Disaster and Emergency Management Presidency" numbered 5902 enacted in 2009, significant changes have been made in the field of disaster management in our country. In our schools, old systems such as the civil defense club or civil defense plans continue to develop the disaster culture, but recently, school disaster plans have been created in many schools.

As a result of the research, 9 main topics of measures for the evaluation of emergencies for schools were determined. There are 120 evaluation criteria questions in the created guide. The level of the risk was revealed by scoring the criteria with L- Matrix risk assessment. In Fevzi Paşa primary and secondary school, which we consider as an exemplary school, 100 of these criteria were evaluated, and while 52 of the 100 criteria were positive, 48 of them were negative. It has been determined that the identified risks are problems that can be solved by the school administration.

When we look at the guideline evaluation results, we can say that it is successful. As a result, these assessments for emergencies, which are the basis of disaster plans, should be disseminated. As can be seen as a result of the evaluation, we have deficiencies in our educational institutions. It is clear that for a safer and more comfortable education, evaluations and plans need to be made realistically.

The most important task falls to the Ministry of National Education. This duty is to establish disaster and emergency boards in schools, to ensure that they work effectively, and to make legal arrangements for the preparation of disaster and emergency management plans. To support and develop the system to be established, the general directorate can be established as a unit under the ministry. In this way, the emergency analysis made by schools will be reported first hand, and the 
time to cover deficiencies in structural and non-structural security measures will be considerably shortened. Each institution should prepare realistic scenarios for themselves and apply them at least 2 times a year in line with the plan they prepared beforehand. Exercises should be done without informing staff and students.

It is very important to keep plans and analyzes up-to-date tomake our schools and educational institutions safer. It has been observed that there are not enough studies on this subject in our country. More emphasis should be placed on studies and education buildings should be upgraded to safer levels. More training on exercise and disaster training should be organized and disaster training should be included in standard training curricula. While making school disaster plans, priority should be given to designing individual plans and then completing family plans, and disabled individuals should be given more space when making school disaster plans. As seen in the researches, disabled individuals are often not included in the plan. The database of the Ministry of National Education school disaster plans should be created and the analyzes and plans made should be stored there.

A budget should be prepared for situations that are identified after the assessments regarding emergencies and are considered to be deficient. The budget should be established as a unit in the Ministry of National Education. It is recommended to improve the situations specified in the studies to be carried out on this subject.

\section{References}

Akpınar, Burhan ve Köksalan, Bahadır (2003), Emergency Situations and School. Firat University Journal of Social Sciences, 13 (1), 151-158.

Barnes Jill M. (2013). “School Disaster Needs For Students With Disabilities: Voices From The Field" University Of California, Los Angeles.

Fox Michael H., White Glen W., Rooney Catherine, and Rowland Jennifer (2007). "Disaster Preparedness and Response For Persons With Mobility İmpairments: Results From The University Of Kansas Nobody Left Behind Study", Journal of Disability Policy Studies, 17(4), 196-205.

IMO, (2011), 19 May 2011 Simav Earthquake and Structural Damage Report, Chamber of Civil Engineers, Disaster Response Preparedness Board.

Kişioğlu Ahmet N., Demirel Reha ve Öztürk Mustafa (2005), Assessing The Indoor Environment Of Primary Schools in The Southwest of Turkey. Indoor Built Environment, 14(2), 141-145.

Koçkan, Çağdaş, (2015). Risk Management in Natural Disasters. 3. Turkey Conference on Earthquake Engineering and Seismology, 1-8, Izmir.

Lenon Tom and Moore David (2003), The Natural Fire Safety Concept-Fullscale Tests At Cardington. Fire Safety Journal, 38,623-643.

Marrion Christopher, Milke James and Kodur Venkatesh (2004), “A Overview Of Fire Protection in Buildings". World Trade Center Building Performance Study, Federal Emergency Management Agency the USA.

Özmen, Bulent; (2000), Damage Status of 17 August 1999 Izmit Gulf Earthquake (with Numerical Data). TDV / D 010-53, Turkey Earthquake Foundation, 132 pages.

Peruman Chaney Suzanne and Lindsay M. Sutton (2013), Students and Perceived School Safety: The Impact of School Security Measures. American Journal of Criminal Justice, 38(4), 570-588.

TMMOB, (2003). 'Chamber of Civil Engineers May 1, 2003, Bingöl Earthquake Evaluation Report, Technical Power, Issue: 127.

Turkey Newspaper: URL: https://www.turkiyegazetesi.com.tr/yasam/433345, Accessed: 02/23/2019. 